\title{
LIMB SALVAGE PROCEDURES FOR MANGLED LOWER EXTREMITIES: HOW I DO IT
}

\section{ANTHONY UDOSEN, IKPEME IKPEME AND NGIM NGIM}

(Received 15 August 2008; Revision Accepted 25 March 2010)

\begin{abstract}
:
Majority of open fractures in Nigeria result from road Traffic Accident (RTA). This is partly due to bad roads and reckless use of motor cycles as the main means of intra-city transport. (Udosen, et al, 2004; Udosen, AM, Ugare G, 2005) These are precarious injuries associated with severe complications leading to amputation. This procedure devised by the authors was designed to reduce these complications, particularly because amputation is not yet acceptable in our environment, where ignorance, poverty and stigmatization are common. This procedure is simple and cheap and has a satisfactory result in an environment of limited resources. The study was done at the University of Calabar teaching hospital within a period of 6years. 62 limbs in 60 patients were salvaged using this procedure at an average of about 10 salvaged limbs per year. $66 \%(41)$ of them had regained full function while $28 \%$ (17) were still undergoing various forms of rehabilitations. $6 \%$ (4) had amputation because of flail limbs and or severe infections. Male: female ratio was 4:1 and the average age was 32years (17-52yrs). All the injuries were caused by road traffic accident and $60 \%$ of this were due to motor cycle accidents. The average mangled extremity severity score (MESS) for the injured limbs was 4.5 (3-7). Complications encountered in the study included pin tract infection 58\%,wound infection $26 \%$,Chronic osteomyelitis $12 \%$,gross deformity and flail limb $6 \%$,graft failure $6 \%$, Chronic pain $4 \%$ Improvement on this method requires adequate funding and provision of necessary equipment as well as training of personnel.
\end{abstract}

KEYWORDS: Mangled extremity, limb salvage, Ignorance, Debridement

\section{INTRODUCTION:}

Amputation in many instances is now considered as the first step in returning the patient to a normal and productive life. (Ngim, et al, 2005; Onuminya, 2004). The increasing application of sophisticated technology to prosthetic research and design, techniques and rehabilitation in advanced societies has helped in changing attitudes in those societies. This form of treatment for certain diseases is not yet fully and readily acceptable in our society. (Ngim, 2005). In our society, this is not readily practicable because of ignorance and poverty which militate against such intervention processes. Lack of adequate rehabilitation in many instances also prevents the return of the patient to a fully functional life. Therefore, the decision to accept an amputation continues to be difficult hence the need for alternative measures.

One aim of this work was to devise a simple and affordable regimen to salvage limbs which otherwise would have merited ablation. These limbs are those involved in Type 111 open fractures (mangled limbs). Open fractures are classified into type 1, 11 and 111 . Type 111 open fractures are fractures with extensive soft tissue and possible neurovascular damage. (CourtBrown et al, 1997; Gustillo et al, 1990; llizaov GA, 1992;
Efem SEE, 1988; Ud, 2004; Helfet, et al , 1990). It is associated with severe crushing, fracture comminution and contamination. These are subdivided into three grades, Grade 111A, when the fracture can adequately be covered by soft tissue despite extensive soft tissue damage. $111 \mathrm{~B}$ is a fracture that cannot be covered by soft tissue and there is periosteal stripping as well as severe comminution and contamination. In grade $111 \mathrm{C}$, there is in addition to the above, an arterial damage that needs repair.

\section{PATIENTS AND METHODS:}

The patients included in this work were mainly those with Type 111B Open tibial fractures without vascular compromise who reported at the University of Calabar Teaching Hospital, Calabar from January 2002 December 2007. The demographic data of the patients as well as the source, grade and site of injury, the treatment methods, complications and final outcome were documented. These data were collated from patients' case files and the operation registers of the unit. Ethical clearance was obtained from the institution. All the limbs in the study were graded using the mangled extremity severity score (MESS). Excluded from the study were patients who reported with complications

Anthony Udosen, Orthopaedic and Trauma unit, Department of Surgery, University of Calabar Teaching Hospital, Calabar, Nigeria.

Ikpeme Ikpeme, Orthopaedic and Trauma unit, Department of Surgery, University of Calabar Teaching Hospital, Calabar, Nigeria.

Ngim Ngim, Orthopaedic and Trauma unit, Department of Surgery, University of Calabar Teaching Hospital, Calabar, Nigeria. 
such as gangrene and those with type 111c open fractures (those who required amputation). Patients who abandoned treatment before final assessment (incomplete data) were also excluded.

Sponsorship: There was no form of sponsorship for this study.

\section{SURGICAL TECHNIQUES:}

Some of the patients who came with multiple injuries and shock were resuscitated appropriately. Tetanus prophylaxis according to the immune status of the patient is a common practice in our centre.

Investigations: Pre and Postoperative radiographs were done on all the patients. Routine tests included; haemoglobin, HIV Serology, Urinalysis, Grouping and cross matching while others such wound swab microcopy were done only when necessary.

The definitive management for each patient was as follows:

\section{Wound Debridement:}

The following procedures were carried out under general or Spinal Anaesthesia:

(See Fig. $1 \&$ 2)

i. Wound cleansing and cautious removal of devitalize Tissues.

ii. This was done with hydrogen peroxide and copious saline irrigation (4- 6 litres). All foreign bodies, debris and devitalized tissues were carefully removed during this process because they form nutrient media for bacterial growth.

iii. Wound excision and Extension.

The extent of wound excision and or extension depended on the degree of contamination/maceration and how early the patient reported to us. Generally we do minimal wound excision with adequate extension where necessary. Cut nerves were tagged and tendons were left alone to be covered by granulation or flaps. We never had occasion to do surgical Debridement more than once because subsequent biological or chemical debridement was very effective.

\section{iv. Chemical Debridement.}

We use Honcrivine (i.e. a pharmacological preparation of natural honey and acriflavin) to augment surgical wound debridement (Efem SEE, 1988). This has a wound cleansing and antibacterial property. It also promotes tissue regeneration but should not be used on exposed bones as it causes dehydration with subsequent necrosis. Honcrivine wound dressing was done once or twice a day after surgical Debridement and was continued until wound were fully granulated and contracted. Wounds with exposed bones were dressed with magnesium sulphate solution and normal saline.

\section{Soft tissue Management:}

i. BONE COVER

This was done with occasional local muscle flaps while majority of those with intact periosteum were left for granulation tissue to cover.

\section{ii. SKIN COVER.}

We do not practice early skin grafting (i.e. within $72 \mathrm{hrs}$ ). Few wounds were covered with local composite flaps.
Majority of the wounds were covered with secondary split skin grafts about 4-12weeks post injury. Primary wound closure was not allowed even when the skin flaps were adequate for apposition. This was part of the measures to reduce wound infection and breakdown. It is important to note here that our hospital did not have conventional plastic and reconstructive facility at the time of this study.

\section{Emergency fracture Stabilization and care:}

The fractures were reduced and stabilized with cheap external fixators within 12-72 hours of reporting to hospital. The pins-in-plaster fixation technique was the commonest fixation method used (Fig.3). The use of external fixator helped in soft tissue management thereby reducing infection rate. It allowed for early mobilization of some patients and promotes wound healing. We never had occasion to do internal fixation even in those wound that had enough flaps for primary closure. This would not have been possible because most of these patients could not afford the price of implants and there was no subsidy or any form of insurance for them.

\section{Management of Exposed Bones and Bone loss: \\ All loose bone fragments and those with flimsy} periosteal attachments were removed during Debridement. Exposed bone cortices not covered by periosteum or flaps were decorticated within 6-10 weeks of injury. This was eventually grafted after adequate coverage by granulation tissues.

Segmental bone loss either primary at the time of injury or through decortications were managed by massive cancellous bone grafts and or tibio-fibula synostosis. The external devices were removed after 812 weeks and a functional brace or Sarmiento cast applied.

\section{Supportive Measures:}

Antibiotic Cover: We use third generation cephalosporin such as Rocephin (Roche), Oframax (Ranbaxy) and metronidazole for those who could afford. For the poorer group Ampiclox or ciprofloxacin, gentamycin and metronidazole were used. This was given for a minimum of 7-14 days. Cultures were done where necessary (Where the patient could afford) and antibiotic changed accordingly.

Other Drugs: These included haematinics, vitamins/mineral, analgesics inform of pentazocin, diclofenac potassium (cataflam) and paracetamol. Other drugs included calcium preparations and anti-thrombotic prophylaxis.

\section{REHABILITATION:}

Soon after skeletal stabilization wounds were firmly bandaged after dressings and patients were encouraged to start passive joint exercises. The limbs were elevated on splints while nursing and wound care continued. Within 2-3 weeks some could move with crutches (nonweight bearing on the affected side). This continued till 16-24 weeks to allow for the healing of grafts. Most patients with very severe and complex injuries did not bear weight for about 6-10 months. 
RESULTS

Seventy-seven patients were included in this study, but 11 left against medical advice after initial treatment while 6 were lost to follow up after discharge from hospital and had incomplete data. Final analysis was done on 62 limbs in 60 patients who met the inclusion criteria. This gave an average of about 10 salvaged limbs per year. $66 \%(41)$ of them had regained full function while $28 \%$ (17) were still undergoing various forms of rehabilitations. $6 \%$ (4) had amputation because of flail limbs and or severe infections. These were among those who came after initial mismanagement at traditional bone centres. Male: female ratio was $4: 1$ and the average age was 32years (17-52yrs). All the injuries were caused by road traffic accident and majority $(60 \%)$ were due to motor cycle accidents. The average mangled extremity severity score (MESS) for the injured limbs was 4.5 (3-7).
Two female patients had bilateral tibial fractures. 28 patients $(45 \%)$ had standard external fixators while $(55 \%)$ were treated with pins-in- plaster construct. 32 patients (44\%) had decortications and subsequent bone grafting. Majority of patients $(52 \%)$ had injuries at the middle third of tibia while (30\%) and (18\%) had distal and proximal or knee injuries respectively. Complications encountered in the study included the following:

1. pin tract infection $58 \%$

2. wound infection $26 \%$

3. Chronic osteomyelitis $12 \%$

4. gross deformity and flail limb $6 \%$,

5. graft failure $6 \%$

6. Chronic pain $4 \%$

Wound cultures yielded staphylococcus in $36 \%$, streptococcus in $12 \%$, pseudomonas and coliforms in $10 \%$ and mixed growth in $26 \%$. $14 \%$ of the patients could not afford such tests.

\section{Example salvaged mangled limb}

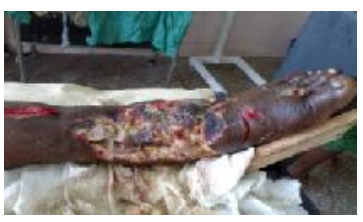

Fig. 1: A typical mangled limb

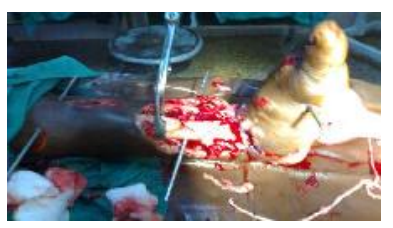

Fig. 2: Same limb during debridement

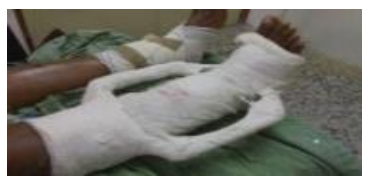

Fig. 3: Pins-in-plaster fixation

\section{DISCUSSION}

The above procedure was borne out of a desire to alleviate the suffering of the ignorant and poor masses of our community. In our society, the combination of poverty and ignorance contributes to late presentation to hospital and encourages the patronage of inappropriate traditional interventions (Udosen AM, 2004). Such habits continue to hinder the optimization of early and appropriate surgical intervention processes. The authors' aim was to salvage the limbs using affordable and available materials and method. Some of the splint/devices were designed and produced by the authors. ${ }^{11}$

\section{SOCIO-ECONOMIC STRESS}

There is complete lack of social support for the victims in addition to the poor national economy and unemployment. Most of the patients were commercial motorcyclists with large families. This agrees with other reports by trauma researchers in Nigeria (Udosen AM et al, 2004; Onuminya JE, 2004). Treatments for some of these patients were sponsored by the authors and other philanthropists in the hospital.

\section{IGNORANCE:}

In our society, ignorance is a major reason for increasing patronage of wrong traditional practices. There is also poor acceptance of amputation processes for fear of stigmatization. This high degree of ignorance and superstition associated with bone and joint ailments, usually lead to increased incidence of complications (Udosen AM, Ikpeme IA, etal, 2004. This project was aimed at helping the poor masses as well as creating awareness that such mangled limbs could only be salvaged in a hospital setting. The satisfactory result recorded in this study is related to the inclusion criteria, i.e. the early reporting to hospital, vascularity and prompt surgical interventions.

\section{LACK OF CONVENTIONAL MEDICAL FACILITIES:}

Apart from the paucity of personnel, our major problem was lack of basic equipment to manage acute trauma. This includes facilities for emergency resuscitation, investigation, treatment, rehabilitation and other supportive care. The llizarov devise is one of the modern methods of managing such limb injuries particularly when it is associated with bone loss and deformities/shortening (llizarov GA, 1992). The pins-inplaster fixation technique was the commonest fixation method used in this protocol (Udosen AM, Ikpeme, IA, et al, 2004). We hope to improve on these methods if given the necessary support. The authors are grateful to Dr. Zirkle Lewis, founder and President of the surgical Implant generation network (SIGN), who supplied free SIGN implants and instruments to the University of Calabar Teaching hospital. This has also helped the poor, even as we are pleading with management of the hospital to waive some of the operation fees. (NB: SIGN implant were not used in this study) 
PROBLEMS OF TYPE 111 OPEN FRACTURES OF TIBIA (MANGLED EXTREMITIES)

Some of the problems associated with this type of injuries and their management in our environment are highlighted below.

\section{LOSS OF BLOOD SUPPLY:}

This can be primary from the injury or secondarily from infection and or mismanagement. Prompt splinting, Debridement and stabilization is recommended if such limb is to be salvaged (Gustillo RB, et al, 1990). All the fractures included in the study had intact blood supply pre and postoperatively.

\section{ANATOMICAL LOCATION OF THE TIBIA BONE:}

The subcutaneous nature of the tibia makes it more prone to injuries. The relatively poor vascularity of the anterior tibia also promotes poor healing which can be made worse by wrong treatment. For the above reasons all anterior tibial injuries should be handled carefully and promptly. Lesions on the proximal two thirds healed better than those on the distal third.

COMMINUTION: This is usually an evidence of severe impact. The outcome is made worse if the patient presents late. It may be associated with loss of fragments and vascularity. The common complication is chronic Osteomyelitis (Court-Brown, et al, 1997).

\section{INFECTIONS:}

Infection rate ranges from $10 \%$ to $30 \%$ in type 111 open fractures. This can be worsened by late presentation and mismanagement. The $26 \%$ wound infection rate and the $12 \%$ of chronic Osteomyelitis in our series are in line with other reports within and outside Africa on type 111 open fractures (Udosen AM. 2004; Helfet DL, et al. 1990, Ikem IC, et al, 2004).

\section{ASSESSMENT OF OPEN TIBIAL FRACTURES:}

15. Apart from the Gustilo and Anderson classification of open fractures Helfet DL et al in 1990 also introduced the Mangled extremity severity score (MESS). This forms a useful guide in deciding amputation or salvage of a mangled limb. It takes into account the degree of skeletal and soft tissue injury, shock, ishaemia and age of the patient. Limbs with MESS score of 7 and above may not be salvageable, whereas scores of 3 to 6 are salvageable. Limbs included in this study had the mangled extremity severity score (MESS) of about 3 to 6 and were salvageable (Leaper DJ, 2002; Lawrence AW, et al. 2007; Robertson PA, 1991). However, the successful use of this system requires experience and sound clinical judgment. The satisfactory outcome of this study was partly a result of the prompt management of the injuries and shock as well as youthful ages of the patients in the study (mean of $32 \mathrm{yrs}$ ).

\section{Methods of wound Debridement:}

Known methods of wound debridement include surgical excision using scalpel and scissors; Mechanical method using hydrotherapy and wound irrigation are also used. Autolytic method using hydrocolloids and hydrogels and the use of enzymatic preparations such as streptokinase or streptodornase are recommended in certain dirty wounds (Leaper DJ, Harding KG, 1998). Biological method such as maggot therapy is now in vogue in certain centres in Europe, America and South Africa. The use of Chemicals such as hypochlorite is rarely done today (Steenvoorde P, et al,2007). In this work, a combination of minimal excision, irrigation and chemical debridement was used. This was dictated by the nature of wounds and availability of resources (Leaper DJ, Harding KG, 1998.).

\section{BONE AND SOFT TISSUE LOSS:}

This may occur at the time of injury or later following avascular necrosis from severe infections. These can be managed by various forms of grafting or distractive callotaxis. Severely mangled limb with extensive bone and soft tissue loss may benefit from early amputation (Udosen AM, Glen E, et al, 2006). In this centre we practice autogenous bone graft and ipsilateral tibio-fibula transfer with good results. Exposed bones were managed by saline dressing and decortications with or without bone grafting (Udosen AM, Essien DE, 2007; O.O. Adegbehingbe, et al, 2008).

\section{Limb salvage Versus Amputation}

Most of the amputations done in our society are due to mismanagement of limb injuries by traditional healers and late presentation to the hospitals (Ngim et al, 2006). Otherwise the primary aim of the traumatologist is to salvage all injured limbs. It is wrong to believe that amputation is the only option for treatment of severe limb injuries in hospitals (Helfet et al, 1990). However, the decision to salvage a mangled limb must take into account the severity of the injury, the time of presentation, available facility and expertise as well as presence or absence of other complications. Sometimes, in severely mangled limbs, early amputation may be more beneficial not only in saving life but also in the overall quality of life and function ( Leaper DJ. 2002, Steenvoorde P, et al. 2007; Udosen AM, Essien DE; 2007). To obtain maximum benefit from the decisions to salvage or amputate, adequate and timely explanations should be given to the patient. The availability of adequate and functional rehabilitation facility should not be overemphasized.

\section{CONCLUSION}

Open fractures of the tibia and fibula is a major cause of morbidity and mortality in Nigeria and indeed Africa. The remote causes of these are poverty, ignorance and poor healthcare planning. These together with inadequate health facility militate against early access to proper treatment. This leads to unnecessary loss of limbs and lives. By the above method the authors have saved about 60 limbs and lives in 6 years. This took a lot of sacrifice and patience on the part of the surgeons as well as intense persuasion to discourage the patients from leaving the hospital to the traditional healers (Udosen AM, Glen E, et al, 2006).

\section{RECOMMENDATIONS}

Intensive health education, dissemination of correct health information would help in debunking the old superstitious beliefs and encourage patronage of 
modern practices. Provision of basic facilities for emergency management of trauma victims and institution of proper and timely interventional measures would prevent unnecessary loss of limb and lives. Government and philanthropist should promote manpower development in the area of Traumatology. Eradication of poverty and institution of a workable health insurance policy that would include the rural dwellers would reduce this menace. Trauma, particularly, from Road Traffic accident is an epidemic and should be addressed in the primary healthcare policy. Some of the authors have started small scale designing and fabrication of standard appliances which are cheap for use in our environment. Research grants /sponsorship may help greatly in this direction. Large scale and long term study of the management and outcome of mangled lower extremities using patient and surgeon-controlled variables is recommended in our environment (Leaper DJ, 2002).

\section{ACKNOWLEDGEMENTS}

The efforts of the staff of orthopaedic unit as well as the theatre unit of the University of Calabar Teaching Hospital are hereby appreciated. Thanks to the Ethical committee of the University of Calabar Teaching Hospital for allowing the study and report of this procedure.

\section{REFERENCES}

Court-Brown, C. M., Cross, A. T and Hahn, D. M et al., 1997. A Report of the BOA/BAPS Working Party on the Management of Open Tibial Fractures.

Efem, S. E. E., 1988. Clinical Observation on the wound healing properties of honey. British J Surg, (7): 679-86.

Gustillo, R. B., Merkow, R. L and Temple, D., 1990. Current concepts: the management of open fractures. J B J Surg. (72A): 299-304.

Helfet, D. L., Howey, T and Sanders, R, et al., 1990. Limb salvage Versus amputation. Preliminary results of mangled extremity severity score. Clin Orthop; (256): 80-86

llizaov, G. A., 1992. Transosseous Osteosynthesis. Springer Verlag, Berlin,Heidelberg and New York.

Ikem, I. C., Oginni, L. M., Bamgboye, E. A., Ako-Nai, A. $\mathrm{K}$ and Onipede, A. O., 2004. The bacteriology of open fractures in lle-Ife, Nigeria. Niger J Med. (4): 359-365.

Lawrence, A. W., Michael, J. B and Renan, C. C, et al., 2007. Analysis of Surgeon-Controlled variables in the treatment of limb-threatening Type 111 open tibial diaphyseal fractures. JBJS AM. 89.923-8. DOI: 10.2106/JBJS.F.00776Leaper DJ. Sharp technique for wound debridement. World Wide Wounds.2002 http://www.worldwidewounds.com
/2002/december/Leaper/Sharp-Debridement.ht $\underline{\mathrm{ml}}$

Leaper, D. J and Harding, K. G., 1998. editors. Wounds. Biology and Management. Oxford: Oxford University Press.

Ngim, N. E., Udosen, A. M and Ikpeme, A. I., 2006. Review of seventy consecutive cases of limb Injuries in Calabar: The role of motorcyclists. Nig J Orth/Trauma 5, (2): 38-40.

Onuminya, J. E., 2004. The role of traditional bonesetter in primary fracture care in Nigeria. S Afr Med J. $94,(8): 652-8$.

Adegbehingbe, O. O., Oginni, L. M., Olorunnisola, O. A and Akanbi, O. O., 2008. Exposed Bone Syndrome: Classification and Scoring of Exposed Long Bone. The Internet Journal of Orthopedic Surgery. 8, (1):

Robertson, P. A., 1991. Prediction of amputation after severe lower limb trauma. J Bone Joint Surg [Br]; 73, (5): 816-818.

Steenvoorde, P., Jacobi, C. E and Doom, L. V, et al., 2007. Maggot debridement therapy for infected ulcers: patient and wound factors influencing outcomea study on 101 patients with 117 wounds. Ann R Coll Surg Engl, (87): 596-602

Udosen, A. M., Ikpeme, A. I., Etiuma, A. U and Egor, S., 2004. Major Amputations at the University of Calabar Teaching Hospital, Calabar, Nigeria. Nig. J of Surg. Sc., 14, (2): 60-63.

Udosen, A. M and Ugare, G., 2005. Generalized Tetanus Following mismanaged lower limb fractures by traditional bonesetters. Tropical Doctor (35): 237-239.

Udosen, A. M., 2004. Role of Rural Orthpaedic and Trauma Assistants in Improving Rural Orthopaedic and Trauma Care. Annals of African Medicine 3, (3): 150-152.

Udosen, A. M., Ikpeme, I. A., Umo-otong, U. E and Opone, A. C., 2004. The Use of Pin-In-Plaster Technique in the Management of Complex Tibial Fractures, the Calabar experience. Nig. J of ortho/trauma, 3, (2): 108-112.

Udosen, A. M., Glen, E., Ogbudu, S and Nkposong, E., 2006. Incidence of leaving against medical advice (LAMA) among patients admitted at the Accident and Emergency unit of the University of Calabar Teaching Hospital, Calabar, Nigeria. Nig Journal of Clinical Practice 9, (2):122-125

Udosen, A. M and Essien, D. E., 2007. Producing Indigenous Orthopaedic Splints: The Nigerian Initiative. The Internet Journal of Medical Technology. 4, (1): 
